\title{
INTEGRATING INTERMODAL TRANSPORT WITH LOGISTICS: A CASE STUDY OF THE UK RETAIL SECTOR
}

This is the pre-published version of the text. The final published paper can be found at:

Monios, J. (2015). Integrating intermodal transport with logistics: a case study of the UK retail sector. Transportation Planning and Technology. 38 (3): 1-28.

DOI: $10.1080 / 03081060.2015 .1008798$

\begin{abstract}
Retail traffic is one of the main drivers for the growth of intermodal transport services in the UK. The aim of this paper is to understand the key factors underpinning this modal shift in order to learn lessons for other market and geographical contexts.

Successful retail intermodal logistics involves many actors, thus this paper is based on semistructured interviews with major retailers, third-party logistics providers (3PLs) and rail operators, supplemented by document analysis. The qualitative data are analysed via a conceptual framework derived from the literature.

Despite past successes and the presence of drivers for future growth, the paper identifies many operational issues without current solutions and the presence of ongoing public subsidy. The major conclusion is that the importance of 3PLs, aggregation and multi-user platforms must be recognised by transport planners in supporting the use of intermodal transport by retailers and other large shippers.
\end{abstract}

Keywords Retail, logistics, rail, intermodal transport, integration, distribution 


\section{Introduction}

The objective of this study is to understand the key factors relating to the use of intermodal transport by retailers. The paper thus joins the fields of supply chain, logistics and business management with the transportation literature. Successful retail intermodal logistics involves many actors, thus this paper addresses the retailers themselves as well as rail operators and third-party logistics providers (3PLs).

Retail traffic is one of the key drivers of intermodal transport in the UK. Lessons learned from this success may contribute to an understanding of modal shift in other market or geographical contexts. The need for this understanding derives from a policy background over the last decade in which modal shift from road to rail has been encouraged by governments as one way to reduce carbon emissions (DETR, 1998; European Commission, 2001). While understanding all factors involved in successful modal shift is beyond the scope of one paper, this paper will examine the particular success of large UK retailers to determine what can be learned for other sectors, and in particular what insights can be provided for transport planners in their ongoing work to support intermodal transport growth.

Woodburn (2012) called for interviews with retailers to understand the reasons behind observed trends, as well as an examination of the role of port-hinterland flows in relation to domestic intermodal routes. This paper addresses that call by examining the overlap between rail industry operational issues and the particular needs of the retail market. The paper takes a particular focus on the Anglo-Scottish route as it is the key corridor for these movements, providing the distance and concentration of flows required. Imports through ports are also considered as rail operators manage both port and domestic flows thus the economic feasibility and operational quality of domestic retail flows can be affected by these movements.

The paper begins with a literature review covering the key issues relating to the shift to intermodal transport, the growth of intermodal transport in the UK and the spatial and operational development of the British retail sector. Section three establishes the conceptual framework derived from this literature, extending the recent work by Eng-Larsson \& Kohn (2012), followed by the methodology. Findings are then presented in four separate sections. Section nine uses a meta-matrix to analyse the key factors from the conceptual framework, determining to what extent known issues are represented in the actual case, as well as what new lessons can be learned. These results are then discussed before drawing conclusions. 


\section{Literature review}

\subsection{General issues influencing intermodal transport}

Modal shift from road to rail faces a number of challenges. The customer desires low transit time, reliability, flexibility and safety from damage, and it has been suggested that customers do not perceive that intermodal transport can provide these (RHA, 2007). There is also an issue of visibility of the true cost of rail movements. MDS Transmodal (2002) found that "there are no published rates for rail freight charges and rail freight users have only a poor understanding of their suppliers' cost structures as there are dominant operators in the market and little on-rail competition" (p.49).

Break-even estimates for a route that requires no road haulage have been estimated as low as around $90 \mathrm{~km}$. With a road haul at one end only, the figure is roughly $200 \mathrm{~km}$, and if both pre- and end-hauls are required, the distance is approximately 450km (MDS Transmodal, 2002). Other aspects of intermodal freight transport have been discussed by, among others, Arnold et al. (2004), Janic (2007), Caris et al. (2008), Kreutzberger (2008) and Woodburn (2011). Whether or not a particular product is suitable for intermodal transport includes such considerations as the lead time and size of orders, the value and the physical characteristics of the product. Problems with intermodal transport include distance, lack of flexibility, lead time for service development and the role of the last mile (Bärthel \& Woxenius, 2004; Slack \& Vogt, 2007). In addition, high fixed costs of rail operators and the requirement to consolidate flows on key routes make profitable service development difficult. Setting up a rail service is a complicated task, which is a barrier to intermodal growth and also a barrier to market entry for new rail operators (Slack \& Vogt, 2007).

Eng-Larsson \& Kohn (2012) found that when making a decision to use intermodal transport, the convenience of the purchase was more important than the price. From an operational perspective, they found that other supply chain decisions had to be made to incorporate intermodal transport, such as increased inventory, extended delivery windows, and improvements in planning and ordering due to less flexible departure times. The product characteristics and the flow geography are also important, generally requiring non-time-sensitive ambient goods on major consolidated routes.

Cooperation is needed to achieve economies of scale on certain routes, but research has found industry reluctant to pursue such a strategy (Van der Horst \& de Langen, 2008). Similarly, a service needs to be well-developed before shippers will use it (Van Schijndel and Dinwoodie, 2000). There is also a severe inertia in the industry. Runhaar \& van der Heijden (2005) found that over a proposed ten-year period, even a 50\% increase in transport costs would not make producers any more likely to relocate their production or distribution facilities. Woodburn (2003) investigated the relationship between supply chain structure and potential for modal shift to rail, and found that "for rail freight to become a much more serious competitor to road haulage would require considerable 
restructuring of either the whole logistical operations of companies within supply chains or farreaching changes to the capabilities of the rail industry to cope with the demands placed upon it" (p.244).

\subsection{Intermodal transport in the UK}

The majority of rail freight in the UK has traditionally been bulk, until containers overtook coal for the first time in 2010 (see Figure 1).

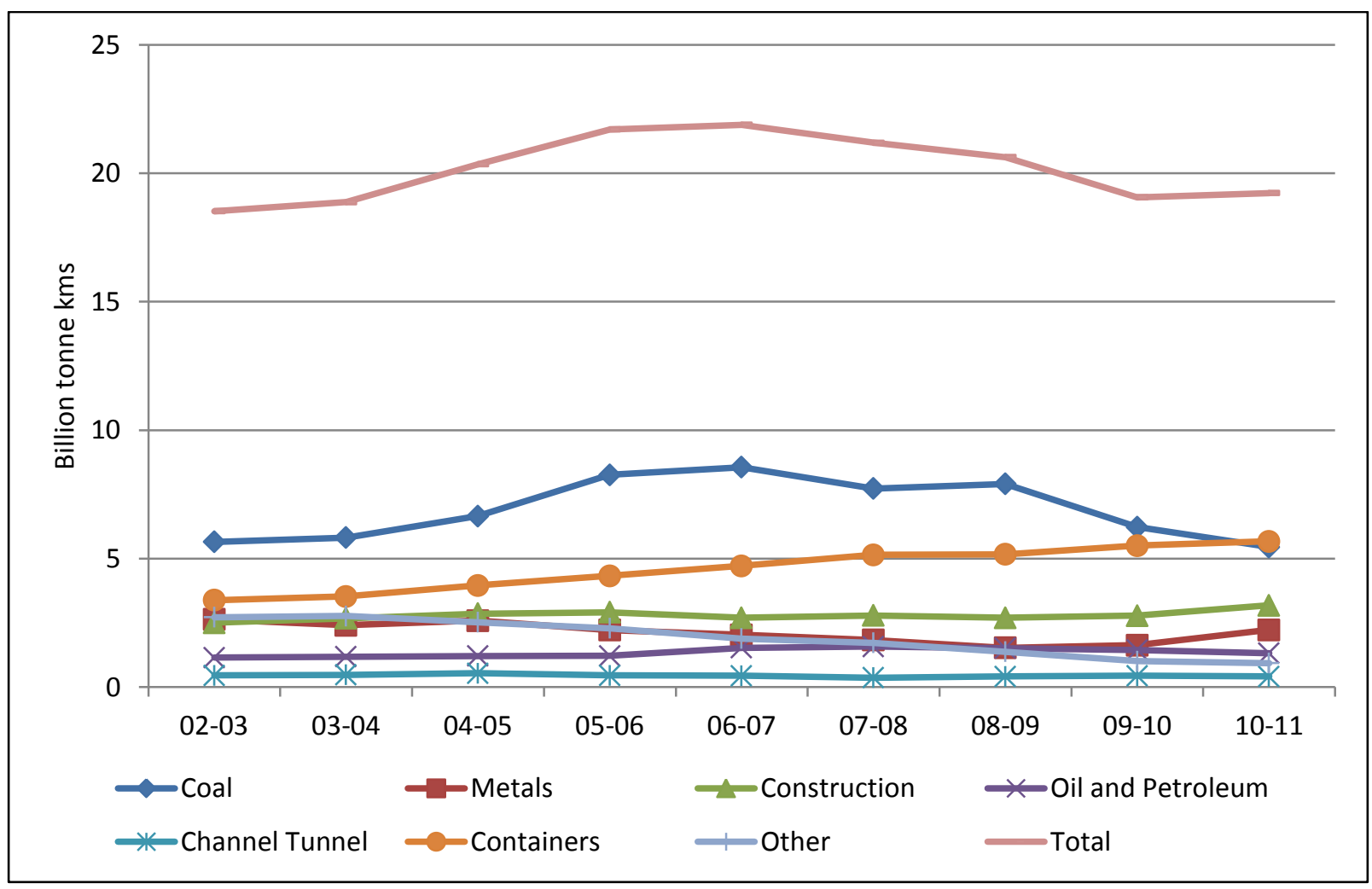

Figure 1. UK freight moved by sector (Source: author, based on ORR figures)

Intermodal transport first developed in Britain as a consequence of the maritime container revolution in the 1960s. Distribution centres (DCs) centralised in the Midlands became key cargo generators and attractors, and, as any port could service the same hinterland, maritime container flows concentrated in the large south-eastern ports. Port-hinterland container services have continued to grow in recent years, with a $56 \%$ increase in the number of these services between 1998 and 2011 (Woodburn, 2012).

Loading gauge restrictions on the UK network is a well-known issue, mostly in northern Scotland and on the East Coast Mainline (ECML), which is used when services are diverted from the primary north-south freight artery the West Coast Mainline (WCML). This is generally more of an issue for maritime containers coming through ports, as these are gradually moving towards a 
standard of high cube (i.e. 9ft6 height rather than the old standard of 8ft6; Network Rail, 2007; Monios \& Wilmsmeier, 2014). While the major parts of the network (Felixstowe and Southampton to the Midlands and thence to Scotland on the WCML) can now take these containers on standard wagons (W10 loading gauge), significant portions can only accommodate them on special low wagons (W9 or W8 gauge). Capacity for long-term growth is known to be constrained, and container imbalances between north and south have been identified (Network Rail, 2007).

Figure 2 shows that, while the large deepsea ports export empty containers back to the Far East, smaller ports, particularly in the north, are required to import empty containers to fill with exports.

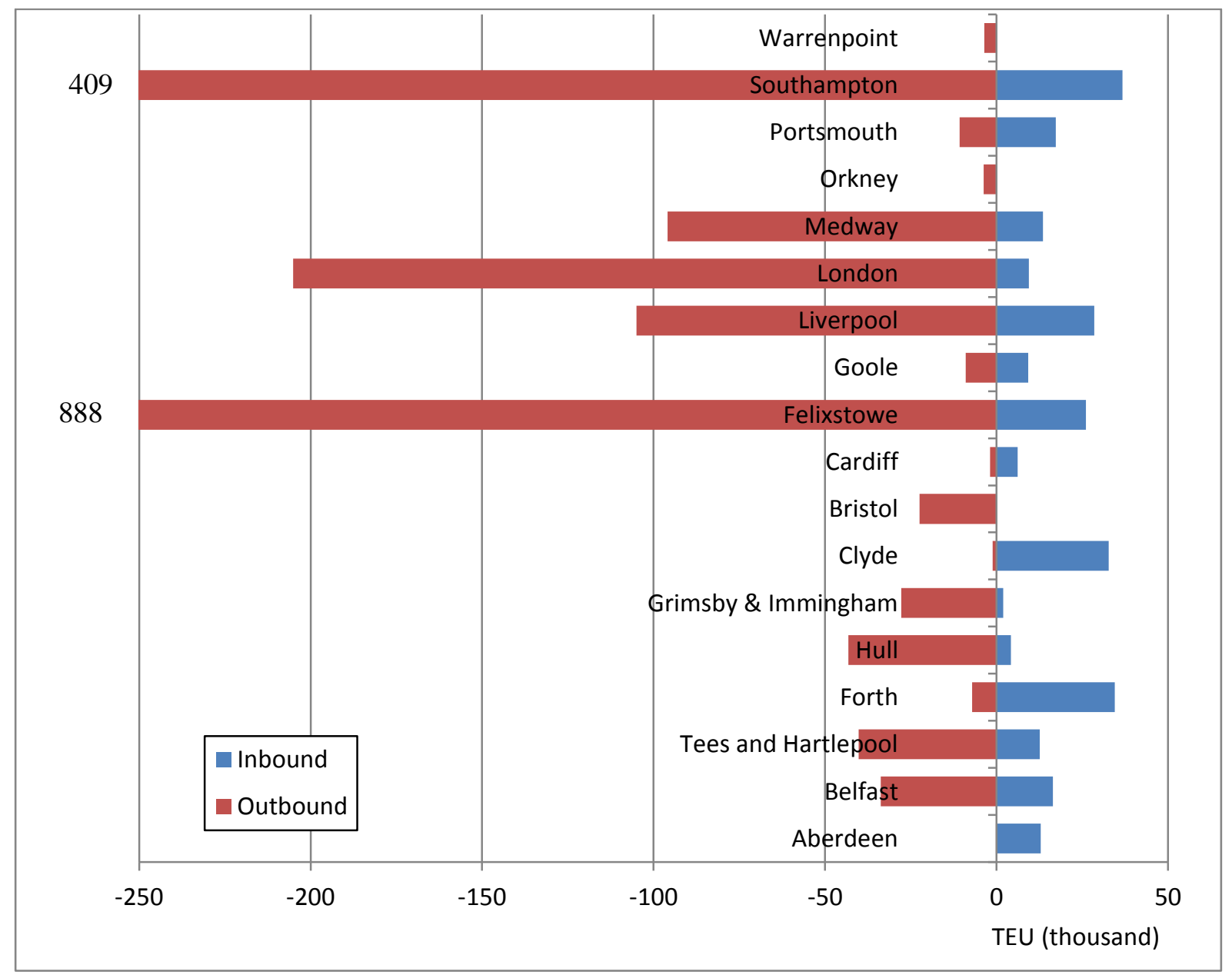

Figure 2. Empty container movements through UK ports 2010 (with Felixstowe and Southampton truncated) (Source: author, based on DfT, 2011) 
The container imbalance occurs because northbound imports to Scotland come mostly as $45 \mathrm{ft}$ pallet-wide road trailers or swap bodies (and now rail containers) as they are retail and other movements from DCs in the Midlands, whereas the majority of Scotland's exports leave as $20 \mathrm{ft} / 40 \mathrm{ft}$ maritime containers either through ports or on rail (Wilmsmeier \& Monios, 2013).

Domestic intermodal traffic took longer than port flows to establish, remaining marginal in earlier years and utilised primarily for industrial products. Over the last decade this market has grown, primarily due to retail flows, with Asda first using rail in 2003 and Tesco following in 2006. These flows are on the Anglo-Scottish corridor (between terminals in the Midlands and central Scotland) and intra-Scottish (between central and northern Scotland, primarily representing continuations of the flows from the Midlands services). These developments were to some extent subsidised by successful use of government funding for intermodal terminals (Woodburn, 2007). These flows have been primarily northbound secondary distribution of picked ambient grocery loads from retail DCs in the Midlands, back loaded with southbound flows from Scottish suppliers, such as soft drinks and spring water (FTA, 2012). Concentration of DCs and intermodal terminals in the Midlands and in central Scotland, with suitable distance between them (see Figure 3), underpinned a high-density Anglo-Scottish corridor with a short "last mile" between DC and intermodal terminal at either end. However, it is not yet clear to what extent rail operators are matching the service characteristics of road haulage, to which retailers are accustomed.

\subsection{Retail logistics in the UK}

UK retailers employ approximately 3 million people and account for almost $6 \%$ of UK GDP (Forum for the Future, 2007; Jones et al., 2008). Nearly $83 \%$ of the retail market of grocery trade in the UK is controlled by five supermarket retailers: Tesco (31\%), Asda (17\%), Sainsbury (16\%), Morrison (12\%) and the Co-operative (7\%) (Scottish Government, 2012).

The spatial distribution of the retail sector has evolved over the last few decades from a system whereby suppliers delivered directly to stores to the introduction of DCs in the 1970s and 80s to the arrival in the 90s of primary consolidation centres (PCCs) (Fernie \& McKinnon, 1991; Fernie et al., 2000; IGD, 2009). Lead times and inventories were greatly reduced as part of impressive efficiency advances over this period.

While the industry deals with external pressures such as market saturation, competition and demographic shifts (Kumar, 2008), a number of operational trends have been observed in the literature, such as the centralisation and relocation of plants and distribution centres, reduction in the supplier base and consolidation of the carrier base (Fernie \& McKinnon, 1991; Lemoine \& 
Skjoett-Larsen, 2004; Abrahamsson \& Brege, 1997; O’Laughlin et al., 1993). Market power has also been concentrated among a few large retailers due to mergers and acquisitions (Burt \& Sparks, 2003). Distribution centres are being optimised and new purpose-built facilities are appearing. Figure 3 illustrates the location of the distribution centres for the five major grocery retailers in the UK (PCCs are not shown). The centralisation in the Midlands is clear, as is the lack of coverage in north England, north Scotland and Wales.

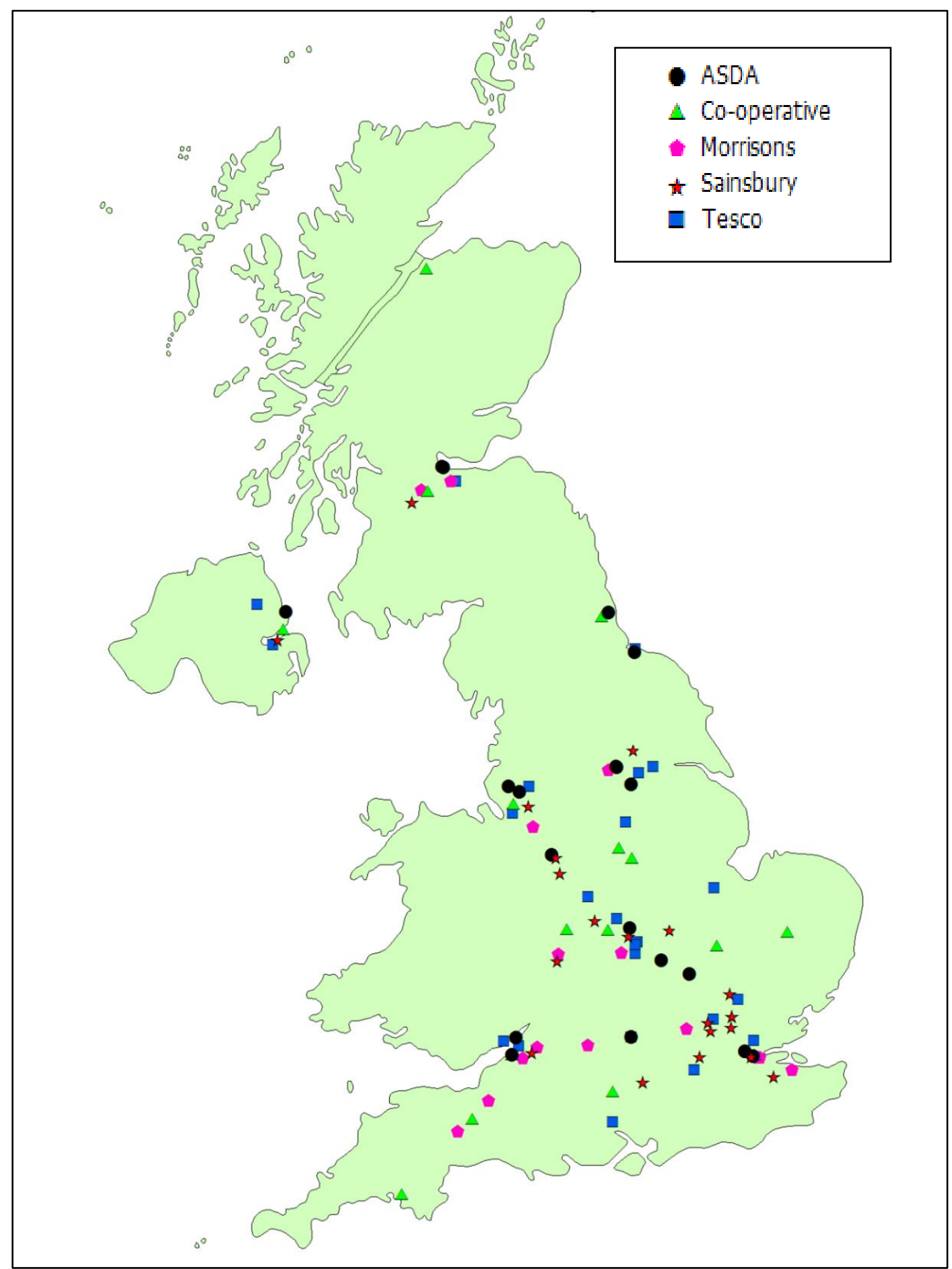

Figure 3. UK distribution centres of the top five supermarket retailers

(Source: author, based on data obtained from retailer websites) 
This paper will look primarily at the Anglo-Scottish movements from DCs in the Midlands to Scotland, as representative of both successful intermodal transport and trends towards greater centralisation. However, port flows will also be considered, as some discussion of locating importfocused distribution centres at ports has taken place in recent years (Mangan et al., 2008; Pettit \& Beresford, 2009; Monios \& Wilmsmeier, 2012) and Tesco and Asda have both located large general merchandise import centres at the port of Teesport. From a port's point of view, this allows them not only to secure cargo throughput, but to earn additional revenue from these activities on their land (Pettit \& Beresford, 2009). Import containers are offloaded from ships, shunted to the warehouse, stripped, and the empty then returned for repositioning. The load will then be reconfigured for inland movement. Potential efficiencies arise as this movement may be direct from the port-based DC to the final store, thus removing the inland DC from the chain.

McKinnon (2009) found that "since 2004, roughly 60\% of the demand for large DCs has come from retailers" (p. S295). Large firms are reducing the number of their DCs while increasing the size and efficiency of those that remain. Fewer, larger DCs means greater centralisation and potentially greater miles travelled, but also greater potential for intermodal transport due to consolidation on key routes. Food and grocery companies currently contribute one in four of all lorry miles travelled in the UK (IGD, 2012).

Greater use of information and communications technology (ICT) has allowed more accurate forecasting and more responsive ordering (thus a move from push to pull); filling these orders without incurring increased transport costs then required a more tightly optimised spatial distribution of facilities, as well as greater integration between primary and secondary networks. Thus some retailers work with hauliers to optimise their distribution (e.g. reducing empty running or reducing inventory holding requirements) or work with suppliers to optimise product flows (e.g. forecasting, planning and ordering). The result of these spatial and operational evolutions has been increasing integration of operations, ranging from increasingly efficient use of backhauling to the implementation of factory gate pricing (FGP), both of which give the retailer greater control over primary distribution thus strengthening its negotiating position (Mason et al., 2007; Potter et al., 2007; Burt \& Sparks, 2003; Towill, 2005).

This period also saw increased use of 3PLs to handle the growing and increasingly complex transport requirements resulting from these developments, as well as more frequent, smaller deliveries from suppliers to reduce inventories, which also encouraged suppliers to make use of PCCs (Smith \& Sparks, 2009; Fernie \& McKinnon, 2003). Distribution facilities continued to evolve, from single product warehouses to composite environments housing ambient, chilled and 
fresh produce, all scanned in and out using barcodes that were integrated within the IT system used for forecasting, planning and ordering (Fernie et al., 2010; Smith \& Sparks, 2009).

Collaboration with competitors is also a key theme in the literature. The subject of retail intermodal logistics includes the retailers themselves as well as rail operators and third-party logistics providers (3PLs). Schmoltzi \& Wallenburg (2011) found that while almost 60\% of 3PLs in their study operated at least one horizontal partnership with other 3PLs, the failure rate was below $19 \%$, against an average failure rate for horizontal collaborations in many industries ranging from $50 \%$ to $70 \%$. The authors also found that, while horizontal collaboration might be thought to be based on cost reduction, the primary motivations revealed in their study were service quality improvement and market share enhancement. Similarly, Hingley et al., (2011) found that cost efficiencies from horizontal collaboration were less important to grocery retailers than retaining supply chain control.

\section{Conceptual framework}

In a similar study to the present paper, Eng-Larsson \& Kohn (2012) constructed a conceptual framework linking the contextual factors affecting the modal shift decision, the contextual factors affecting intermodal transport quality and the resulting operational changes affecting logistics performance (Figure 4).

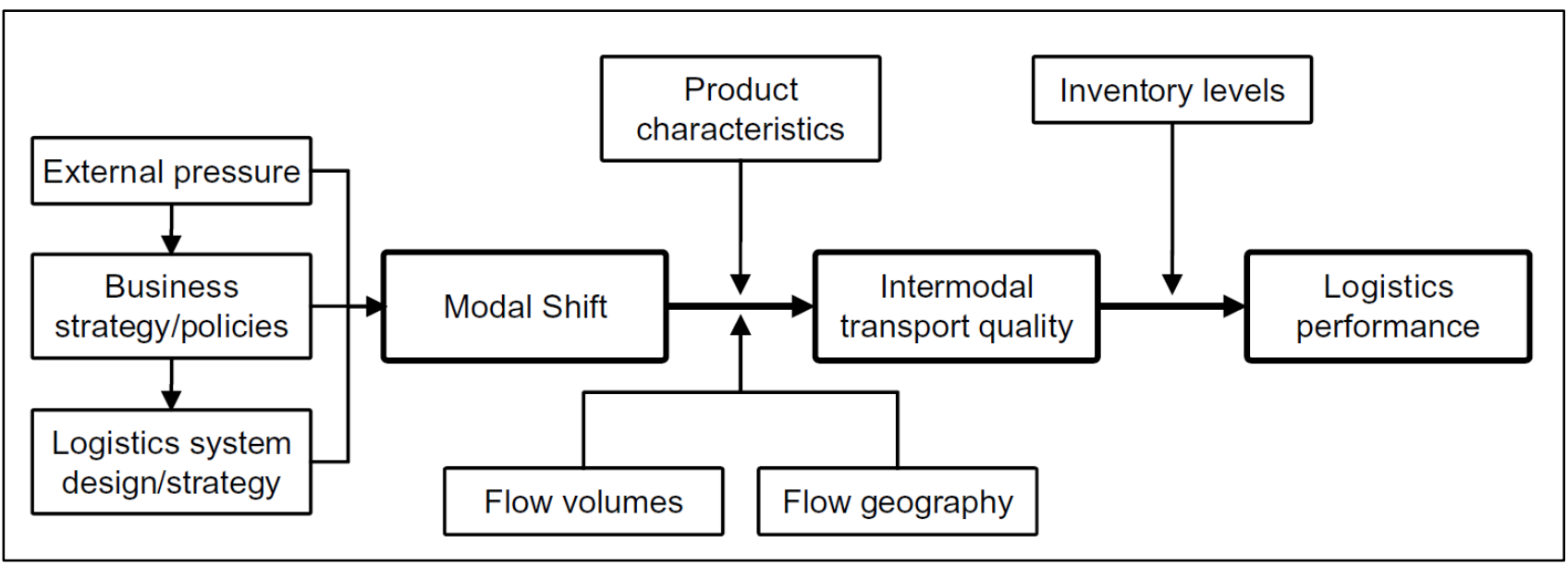

Figure 4. Conceptual framework relating modal shift decision, intermodal transport quality and logistics performance

(Source: Eng-Larsson \& Kohn, 2012)

Rather than addressing all three elements of the framework, this paper aims to understand the second stage of the model in more detail, where the industry characteristics intersect with the quality of the intermodal transport provision. The retail sector in the UK has achieved some 
successful modal shift, due in part to the spatial concentration and distance outlined in the previous section. However, it is not clear how rail operators are matching the service characteristics of road haulage to which retailers are accustomed.

Eng-Larsson \& Kohn (2012) added two new aspects to the second part of their model as a result of their research: system control and carrier performance. These additions concur with the literature review above, where the increasing role of integration (defined as a process whereby the entire logistics system is managed as a single entity) and the issues faced by transport providers (within the same mode as well as across modes) were noted. The literature review on intermodal transport and retail logistics presented in the previous section can now be used to expand the second stage of the Eng-Larsson \& Kohn (2012) model.

The key findings from the literature review are presented in Table 1.

Table 1. Key findings from the literature review

\begin{tabular}{|c|c|c|}
\hline Factor & Sub-factor & Literature \\
\hline \multirow{5}{*}{$\begin{array}{l}\text { Operational } \\
\text { rail issues }\end{array}$} & Infrastructure & Capacity and high-cube clearance issues are known. \\
\hline & Equipment & Wagon and container imbalances are known. \\
\hline & Operations & $\begin{array}{l}\text { Known issues with lead time, backhauls, service development } \\
\text { and general operational complexities compared to road } \\
\text { transport. } \\
\text { The literature assumes a competitive environment for domestic } \\
\text { rail. Little discussion of port vs inland flows. }\end{array}$ \\
\hline & Price & Lack of transparent pricing system. \\
\hline & $\begin{array}{l}\text { Role of government } \\
\text { in intermodal } \\
\text { transport }\end{array}$ & $\begin{array}{l}\text { Government promotes intermodal transport through policy. } \\
\text { Literature suggests that government funding for intermodal } \\
\text { transport has been successful. }\end{array}$ \\
\hline \multirow{7}{*}{$\begin{array}{l}\text { Retail } \\
\text { distribution }\end{array}$} & Primary distribution & $\begin{array}{l}\text { Generally managed by suppliers but increasing control by } \\
\text { retailers. }\end{array}$ \\
\hline & $\begin{array}{l}\text { Secondary } \\
\text { distribution }\end{array}$ & Generally managed by retailers now. \\
\hline & Distribution centres & $\begin{array}{l}\text { Rationalisation and centralisation of DCs, larger purpose-built } \\
\text { composites. }\end{array}$ \\
\hline & Consolidation & Use of PCCs by suppliers. \\
\hline & $\begin{array}{l}\text { Product \& route } \\
\text { characteristics }\end{array}$ & $\begin{array}{l}\text { Primarily ambient/grocery products in retail cages moving in } \\
\text { containers on the Anglo-Scottish route, back hauled by } \\
\text { suppliers. Long distance route between load centres located in } \\
\text { the Midlands and central Scotland. }\end{array}$ \\
\hline & $\begin{array}{l}\text { Horizontal } \\
\text { integration }\end{array}$ & $\begin{array}{l}\text { Uncommon among retailers but some evidence that 3PLs are } \\
\text { increasingly doing so. }\end{array}$ \\
\hline & Vertical integration & $\begin{array}{l}\text { Increasingly integrated supply chains but little in the literature } \\
\text { regarding its role in intermodal transport. }\end{array}$ \\
\hline
\end{tabular}


While the general characteristics of intermodal transport are known from the literature, they have not been considered in direct relation to retailers as their primary users, nor have they been examined in a port vs domestic context, both of which have been identified as important topics needing addressed (Woodburn, 2012).

Similarly, the general characteristics of retail distribution, as shown in Table 1, are relatively well covered in the literature, being to some degree an expansion of the second stage of the EngLarsson \& Kohn (2012) model. The current nature of retail distribution is based on primary and secondary distribution strategies linking large composite DCs centralised in the Midlands with regional DCs and local stores. These operational characteristics created the potential for consolidating flows on the Anglo-Scottish intermodal route.

A third significant aspect raised in the literature is that the roles of vertical and horizontal integration have been instrumental in linking retailers, 3PLs and rail operators in order to establish traffic on these routes. However, unlike operational rail issues and retail distribution, this topic has been inadequately covered in the extant literature. In constructing the conceptual framework, therefore, this issue has been separated from the general discussion on retail distribution to form its own topic. In particular, the role of the 3PL linking the rail operator and the retailer will be foregrounded in the framework for this paper, as it is suspected to be the key element, and one that has not been addressed sufficiently.

The relations between distribution (linking retailers and 3PLs) and intermodal transport (linking 3PLs and rail operators) are depicted in the conceptual framework (Figure 5). The roles of vertical and horizontal integration have been foregrounded as key elements. 


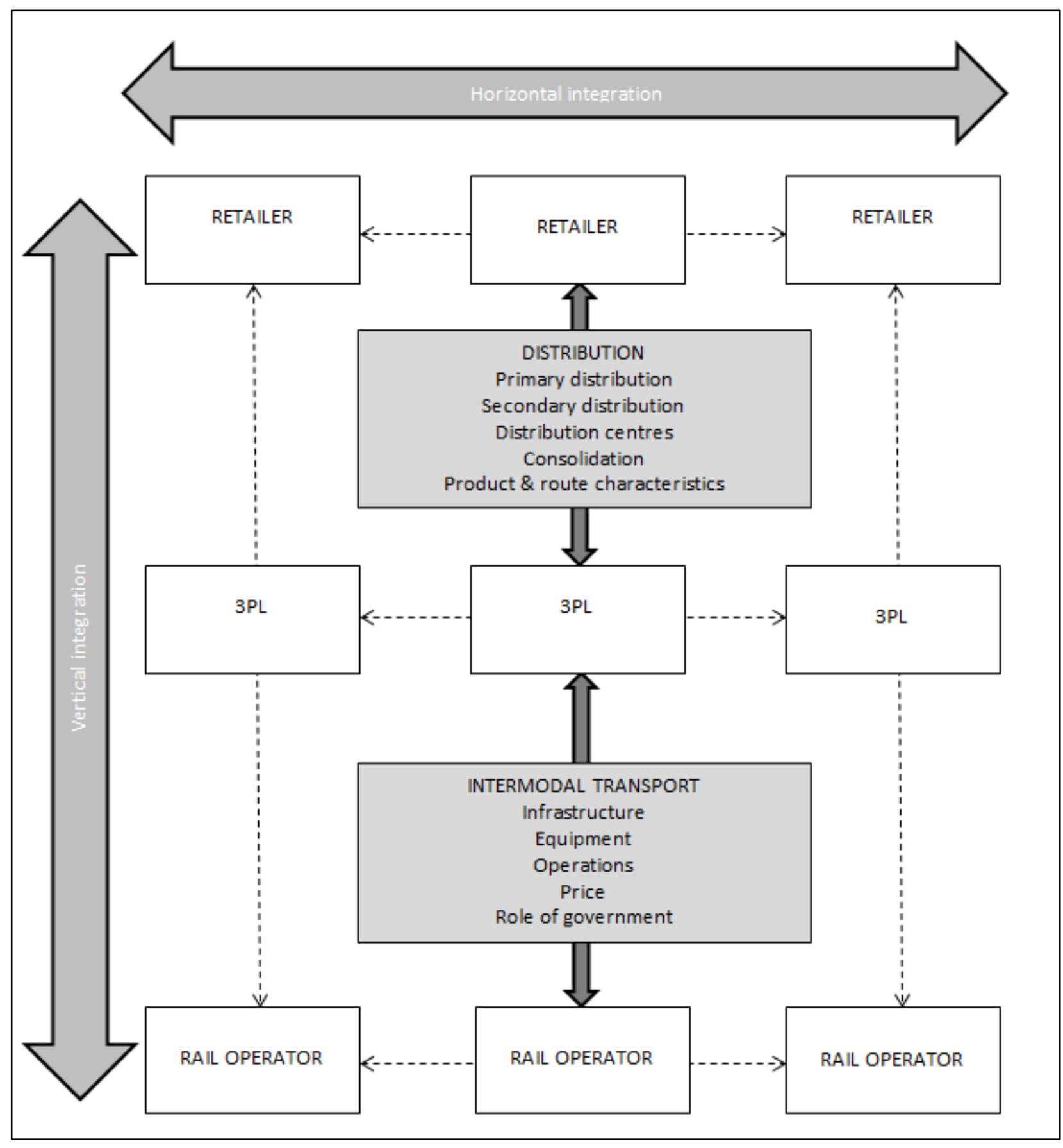

Figure 5. Conceptual framework linking distribution characteristics, intermodal transport provision and the role of integration

\section{Methodology}

The objective of this study is to understand the key factors relating to the use of intermodal transport by retailers, including the role of 3PLs and rail operators. This overall objective has been refined through literature review to produce a conceptual framework highlighting the key relationships and issues to be addressed. In order to collect and analyse data, the research process has been divided into three research questions: 
1. How do operational issues influence the use of rail by the retail sector?

2. How does the spatial distribution of retail logistics influence the use of rail transport?

3. How do strategies of vertical and horizontal integration influence the use of rail transport by the retail sector?

The conceptual framework will be used to analyse the data (see Table 6), comparing the findings with the expectations from the literature to highlight where expectations have been confirmed and where new findings have been established.

The importance of qualitative context-dependent research in logistics has been raised in previous papers (e.g. Näslund, 2002; Aastrup \& Halldórsson, 2008), while other writers have discussed the need for rigorous case study design (e.g. da Mota Pedrosa et al., 2012; Flyvbjerg, 2006; Seuring, 2008; Spens \& Kovács, 2006). In this paper an inductive process has been followed to allow conclusions to emerge from the data; however, the research process has been guided by using the conceptual framework to collate and reduce data on the key factors and sub-factors identified in the literature. This structure also facilitates a comparison between known issues and new findings from the UK case.

The study began with desk research to identify retailers, 3PLs and rail operators involved in intermodal transport. The literature was reviewed to highlight the key issues that could then be explored in depth during the interviews. Informal scoping interviews were conducted with industry stakeholders to confirm these findings and refine the focus of the study before proceeding to the interview stage. In this business, a few large players dominate, thus the interviewees are representative of their sector, and it can be seen from Table 2 and Table 3 that the majority of retailers, 3PLs and rail operators involved in this small market have been interviewed for this study. Three retailers were interviewed (Tesco, Sainsbury and The Cooperative), one wholesaler to provide a contrast (Costco), three 3PLs (JG Russell, WH Malcolm and Eddie Stobart) and two rail operators (DRS and Freightliner). All meetings were with the senior manager directly responsible for planning intermodal services. As retail intermodal logistics is a relatively small speciality, only few staff from each company are directly involved. In most cases, one interviewee was available, and in two cases (Sainsbury and WH Malcolm) two interviewees contributed.

Interviews lasted approximately three hours and each interviewee was given a copy of the interview transcript for approval. The interviews for the study were semi-structured; the interview guide was based on the conceptual framework, and was designed to be tailored during use for each type of interviewee. Thus some questions took precedence over others depending on the interview subject. The research strategy was not based on obtaining opinions on barriers to and opportunities 
for intermodal transport as these are already known from the literature; rather the research design is based on understanding how the structure and operations of the retail business relate to intermodal transport. This is why a case study rather than a survey approach was preferred. Therefore data were also gathered by desk research, in particular document analysis of industry, government and academic literature.

The first step was to review the interview and documentary data several times. The data were then organised and reduced by collating evidence in a matrix based on the conceptual framework, according to a three-stage process of data reduction, display and conclusion drawing and verification (Miles and Huberman, 1994). Gaps in the matrix were identified and filled by follow-up emails as well as further data collection via desk research. An iterative process was followed, moving back and forth between data collection, analysis, interpretation and explanation, making use of triangulation where possible to strengthen interpretations. In this way, the data were reduced into manageable sections, which then guided the presentation under headings and sub-headings used in this paper. A summarised version of the matrix with evidence for each category and sub-category is presented in Table 6.

It is also important not to lose the link to the interview context, as the value of expert interviews is that they provide an insight into actual practice, which should not be subsumed beneath overly abstract categories. Detailed description is particularly important in revealing different strategies across companies. Therefore while the key findings (structured by the research questions and conceptual framework factors) have been summarised in tables presented throughout this paper and collated in Table 6, they have been supplemented by the inclusion of examples of practice drawn from the interviews. Due to commercial sensitivity the detail has been kept fairly general. As an important check on the accuracy and representativeness of the results, as well as the validity of the interpretation and explanation, all interviewees were given the opportunity to comment on the paper.

\section{Use of intermodal transport by retailers}

Before addressing the three research questions, the current use of intermodal transport by UK retailers must be established.

Network Rail, a nominally private but government-owned company owns and operates the track infrastructure, with intermodal terminals owned or leased by private operators. A number of private rail operators compete to run services. There are four primary rail freight operators in the UK: DB Schenker (formerly EWS), Freightliner, Direct Rail Services (DRS) and First GBRf. The other main players are third-party logistics service providers that charter trains from these operators, including 
John G Russell, WH Malcolm and Eddie Stobart. There has been a significant growth for 3PLs because many customers prefer integrated door-to-door solutions.

Table 2 lists all current intermodal rail services on the Anglo-Scottish route (not only those used by retailers), divided into two categories: ex port (direct service between a port and a Scottish terminal) and domestic (between inland terminals in England and Scotland). Intra-England and intra-Scotland services are not shown. The table shows that the majority of domestic container rail traffic between Scotland and England uses DIRFT Daventry; currently doing around 175,000 lifts per year, it is the busiest inland intermodal terminal in the UK.

Table 2. List of current intermodal rail services running on the Anglo-Scottish route

\begin{tabular}{|l|l|l|l|l|}
\hline \multirow{2}{*}{ Type } & Service & Traction & Management & $\begin{array}{l}\text { Frequency } \\
\text { per week }\end{array}$ \\
\hline \multirow{4}{*}{ Ex port } & Felixstowe - Coatbridge & Freightliner & Freightliner & 5 \\
\cline { 2 - 5 } & Southampton - Coatbridge & Freightliner & Freightliner & 5 \\
\cline { 2 - 5 } & Tilbury - Coatbridge & Freightliner & Freightliner & 5 \\
\cline { 2 - 5 } & Liverpool - Coatbridge & Freightliner & Freightliner & 5 \\
\hline \multirow{5}{*}{ Domestic } & Tilbury-Barking-Daventry-Coatbridge & DRS & JG Russell & 2 daily x 5/6 \\
\cline { 2 - 5 } & Daventry - Mossend (DB Schenker) & DB Schenker & Stobart & 6 \\
\cline { 2 - 5 } & Daventry - Mossend (PD Stirling) & DRS & WH Malcolm & 5 \\
\cline { 2 - 5 } & Daventry - Grangemouth & DRS & WH Malcolm & $6 / 7$ \\
\cline { 2 - 5 } & Hams Hall - Mossend & DB Schenker & DB Schenker & 5 \\
\hline
\end{tabular}

(Source: author, based on interviews)

These intermodal services are all shared user. The ex port services are majority booked by shipping lines as carrier haulage is dominant in the UK for port flows, but smaller users can also book space on these trains directly with Freightliner or through a 3PL or freight forwarder. The other flows are managed by 3PLs serving a variety of customers. The largest sector utilising these trains is the retail sector, therefore this paper will focus on these users as instructive of the larger issues at play. In this research the focus is primarily on grocery retailers rather than other retail sectors such as fashion, and a wholesaler has also been included as a contrast.

Woodburn (2003) noted that "it is notoriously difficult to identify specific rail freight users and volumes from public sources, particularly in the non-bulk sectors" (p.245). For this paper a list of all retailer use of intermodal transport has been compiled by combining the interview data and a recent report by the UK Freight Transport Association (FTA, 2012) ${ }^{1}$. Results are presented in Table 3.

\footnotetext{
${ }^{1}$ FTA (2012) was published during the course of this research therefore it was not used in the initial research design.
} 
Table 3. Use of intermodal transport by large retailers in the UK

\begin{tabular}{|l|l|l|l|}
\hline Retailer & Route & Traction & Management \\
\hline Tesco & Anglo-Scottish & DB Schenker & Stobart \\
\hline Tesco & Scotland to north & DRS & Stobart \\
\hline Tesco & Daventry-Tilbury & DRS & Stobart \\
\hline Tesco & Daventry-Magor & DRS & Stobart \\
\hline Sainsbury & Anglo-Scottish & DRS & JG Russell \\
\hline Morrison & Anglo-Scottish & DRS & JG Russell \\
\hline Costco & Anglo-Scottish & DRS & JG Russell \\
\hline Waitrose & Anglo-Scottish & DRS & WH Malcolm \\
\hline M\&S (DHL) & Anglo-Scottish & DRS & WH Malcolm \\
\hline Co-operative & Anglo-Scottish & DRS & WH Malcolm \\
\hline Asda & Anglo-Scottish & DRS & WH Malcolm \\
\hline Asda & Scotland to north & DRS & DRS \\
\hline
\end{tabular}

As noted in the methodology section, the majority of companies from Table 2Error! Reference source not found. and Table 3 have been interviewed for this study and will be discussed in subsequent sections, but in this section of the paper all retailers will be considered in order to give a complete overview of the UK retail intermodal network.

Tesco is the only retailer large enough to move significant flows by rail, with four dedicated services, matching secondary distribution of picked loads with inbound primary flows, filled out with other materials such as packed-down cages and recycling. Tesco transports $3245 \mathrm{ft}$ loads daily northbound on the Anglo-Scottish corridor, while their new service to Wales takes $3445 \mathrm{ft}$ boxes, and their service to the north of Scotland and the one from Tilbury take 22 containers each. Asda (not interviewed for this study) is the only company that gets close, with 20 loads on the AngloScottish route and 10 going to Aberdeen. Tesco is about to start moving up to 20 loads daily on the Aberdeen route, as well as planning some more potential services in collaboration with DRS, only one of which is likely to be a dedicated service. With the additional Tesco volume, the Aberdeen service is now fully utilised and is about to extend to 7-day operation. In fact, DRS has noted that they have received additional interest from retailers due to the visible success of their Tesco trains.

Wholesaler Costco is the only other significant user of rail transport, sending 10-15 containers daily on the JG Russell service to Scotland. They used to send the Aberdeen deliveries on this train (just to Coatbridge then by lorry to Aberdeen), but because of the timings it was found to be quicker to use road. The train arrives early enough to suit the central belt stores but there would not be enough time to drive it up to the Aberdeen store.

Other users only contribute very small numbers of containers to the shared user Anglo-Scottish services. Sainsbury has been using rail on some primary hauls to bring product of Scottish suppliers to their Midlands DCs, using the shared JG Russell service (although management of this flow has recently returned to the supplier). Morrisons use the JG Russell service in the opposite direction to 
move loads of picked pallets from Northampton to Bellshill. In the past, they have trialled services between Trafford Park and Glasgow, and Coatbridge to Inverness. Waitrose uses the WH Malcolm Anglo-Scottish service, as does DHL for M\&S. M\&S is building its own rail-connected DC at Castle Donington (see below for discussion). The Co-operative is currently running a trial on the WH Malcolm Anglo-Scottish service, taking 2 containers per night, 5 nights per week from the Midlands to their Scottish DC at Newhouse.

\section{Operational issues influencing the use of rail by retailers}

\subsection{General issues}

All rail users interviewed for this paper stated that their use of rail had been extremely reliable. In fact, rail had proved more reliable than road during the hard winter in 2010/11. As shippers gain experience using rail, they know that they can contact a freight forwarder or rail operator and put even a single container on a timetabled rail service. However, to achieve this position (and extend it) has required and will require work on behalf of 3PLs who can provide a door-to-door solution to customers, providing the responsiveness of a road haulier.

The common opinion from the interviews was that Network Rail is very good to work with, but more effort is needed in areas such as path flexibility. For example, not all paths are utilised but incumbent operators are loath to give them up, and need only run a train once a year to retain the path. Some of these could be freed up, and it has also been suggested that some paths are in reality a higher gauge than listed, and this could be cleared up with only some paperwork and a trial run. One interviewee said that they have had to pay double for a terminal to open on a Sunday, so increased Sunday operations would be welcomed by retailers. Night time deliveries to stores would also help, and the London Olympics may open the door for that to be tested.

Government grants (Freight Facilities Grant [FFG] for infrastructure and Modal Shift Revenue Support [MSRS] for operating subsidies) have been instrumental in supporting the shift of retail (and other) flows from road to rail. Most intermodal terminals in the UK have benefited from FFG funding at one time or another, and the funding has supported intermodal development in other ways, such as subsidising the construction of the Tesco/Stobart rail containers. Interviewees were all supportive of the government grants and critical of their reduction and/or removal, ${ }^{2}$ although there were some concerns that the FFG system could have been used more strategically and that the process deterred some projects that might have been successful. Economic and operational realities of the freight business can make it difficult to use this funding strategically (e.g. by using the planning system to designate strategic terminals via a top-down process rather than relying on ad hoc funding applications). In terms of other government incentives, while interviewees considered it

\footnotetext{
${ }^{2}$ FFGs have now been scrapped in England and Wales and significantly reduced in Scotland.
} 
unfeasible to enforce use of rail, the possibility that the Department for Transport (DfT) could in future allow overweight trucks between DCs and intermodal terminals was felt to be more realistic.

Table 4 shows that the key players mentioned in this paper have received significant operational funding for their intermodal services.

Table 4. Recipients of operating subsidies through MSRS intermodal 2010/11

\begin{tabular}{|l|l|l|l|}
\hline Recipient & $\begin{array}{l}\text { Transport } \\
\text { Scotland }\end{array}$ & DfT & Total \\
\hline DB Schenker & $£ 33,994$ & $£ 192,749$ & $£ 226,743$ \\
\hline Direct Rail Services & $£ 310,676$ & $£ 678,817$ & $£ 989,493$ \\
\hline Eddie Stobart & $£ 308,113$ & $£ 328,209$ & $£ 636,322$ \\
\hline Freightliner & $£ 27,977$ & $£ 56,190$ & $£ 84,167$ \\
\hline JG Russell & $£ 136,157$ & $£ 752,158$ & $£ 888,315$ \\
\hline Total & $£ 816,917$ & $£ 2,008,123$ & $£ 2,825,040$ \\
\hline
\end{tabular}

(Source: author, compiled from government sources)

The economic competitiveness of rail must be improved to reduce the requirement for these operational subsidies, but a number of operational problems were raised in both the literature and the case analysis.

The interviewees in this study claimed that asset utilisation is more important than break-even distance, even if made up by a number of short distance services. One interviewee said to "beware of management accountants" because they look at the individual costs of running a train, without considering factors such as utilisation and cross subsidy across their service portfolio. Most freight trains run at night due to path restrictions during the day, with the result that a locomotive and wagon set may sit idle all day. Daytime running is generally possible in Scotland because the lines are not as busy but this is difficult in England. The view of rail operators in interviews conducted for this paper is that if you can keep a train running most of the day then it will make money, so if a train is just sitting idle in a siding then any service, no matter how short, is worth running.

Handling charges necessitated by changing modes have always been a barrier to greater use of intermodal transport, and the lack of visibility of the true cost of rail movements was noted in the literature review. It was suggested by one retailer that the quote they are given is simply based on being "slightly cheaper than road" rather than being based on the actual costs of providing the service; they would like greater visibility of the cost to the provider of the entire rail service, including the trunk haul. This is similar to the greater control over primary distribution sought through use of factory gate pricing. It is a way of removing the need for the retailer to pay a profit margin on top of the base cost of the transport service. Retailers have been able to make intermodal transport more affordable by bargaining the handling price down, but rail operators feel that they cannot go any further or they will not be able to provide the service. 
Obtaining flows in both directions is often the key issue in making intermodal transport economically competitive with road. By integrating their primary and secondary distribution, Tesco has been able to match supplier deliveries inbound to their Daventry NDC with outbound distribution to RDCs. For example, they sell space on their dedicated trains to their suppliers, thus inserting themselves in a chain of vertical cooperation that draws the rail operator, 3PL and supplier together. JG Russell matches flows on rail by sending French wine to Daventry, then the Costco loads to Scotland, then returning from Scotland to the continent with whisky.

More backhauls from Scotland to England are needed to support the Anglo-Scottish services. The feeling from the interviewees is that the loads are there; "it is just a matter of making it work," sometimes just convincing a company that has not used rail before to give it a try. 3PLs feel that there are many companies with a few containers a day that could use rail, or that may require consolidation of less than container loads (LCL) before sending them south by rail. Therefore consolidation could be a key issue to promote further use of intermodal transport and integrate road and rail more seamlessly.

Road operations also need to be understood in order to contribute to supporting the growth of intermodal transport. Road haulage is built into supply chains because of its inherent flexibility, for instance the ability to stagger deliveries. If 30 containers arrived together it could be difficult to handle. "Staggered delivery is easier to manage," one retailer said.

\subsection{Wagons, containers and retail cages}

Retail movements to stores are generally done in cages, and greater economies can be achieved by transporting these in double-deck lorries, which are almost unique to the UK (McKinnon, 2010). A standard lorry takes 45 retail cages, as does a $45 \mathrm{ft}$ rail container, whereas a double-deck lorry can take 72 cages. As confirmed by a retailer in an interview: "because we run double-deck road trailers, it is difficult for the rail operators to compete on price." Double-deck lorries currently form about $20 \%$ of the Tesco fleet. That might eventually get up to around $40-50 \%$ but according to the interviewee it will never be $100 \%$ because of operational reasons.

Most domestic intermodal containers used by 3PLs such as Stobart, WH Malcolm and JG Russell are 45ft "pallet-wide", which allows them to carry the same pallet loading (UK or Euro) as a road trailer. However, their design differs across companies. The Stobart/Tesco containers are curtain siders, which is common on lorries but not on trains. As trains are often required to stop on the line, they can be targets for pilferage, therefore generally rigid boxes are preferred. Similarly, curtain siders, like swap bodies, cannot be stacked as standard maritime boxes can. Another difference between road trailers and rail containers is that HGVs can be compartmentalised for 
chilled, frozen and ambient but current rail containers cannot, which limits their flexibility. All of these operational issues contribute to the decision to use rail (or not).

It was found in the research that containers designed for purely domestic flows (e.g. the Tesco rail containers designed in conjunction with Stobart Rail) are more likely to be standard $8 \mathrm{ft} 6$ height to avoid the loading gauge problem on the UK network. Taking high-cube containers on non-gaugecleared routes means using special wagons such as Megafrets and Lowliners, which are more expensive to buy and to maintain. Similarly, these wagons are generally $54 \mathrm{ft}$ and carry $45 \mathrm{ft}$ domestic boxes, meaning $9 \mathrm{ft}$ of length is wasted per wagon. This is now being addressed by new low wagons that are $45 \mathrm{ft}$ long.

It will be seen in the discussion of primary and secondary distribution that a large retailer like Tesco managing both legs allows them to match flows to increase the economic viability of a service. However, this approach is threatened by the acute container imbalance on the AngloScottish route, as depicted in Figure 2. Interviews revealed that this container mismatch also affects wagon configurations, for example sometimes $45 \mathrm{ft}$ domestic containers are carried on $60 \mathrm{ft}$ wagons designed for $20 \mathrm{ft} / 40 \mathrm{ft}$ deepsea container combinations. This equipment mismatch is also a problem in countries such as the United States where 40ft deepsea boxes are transloaded into 53ft domestic containers. However $53 \mathrm{ft}$ maritime containers are now being constructed in China, so this may soon come to influence global standards.

Interviews revealed that industry discussions have taken place with regard to the possibility of a joint action between retailers (northbound 45ft boxes) and whisky producers (southbound 20ft/40ft boxes). If either one or the other were to use the same type of container and transload the contents at one end, the problem could be resolved, as long as the savings made from matching the flows outweigh the cost of transloading. However, distillers do not want their high value cargo to be handled any more than is necessary, and retailers have no motivation to inconvenience their operations in order to reduce the repositioning costs paid by Scottish shippers.

\section{The influence of distribution patterns on the use of rail}

\subsection{Primary distribution}

Inbound flows into the DC can come from overseas through ports, the channel tunnel or by air, or they can come from within the UK. While the primary focus of this paper is on domestic intermodal transport of grocery products, some discussion of imports through ports is required in order to demonstrate how intermodal transport is based on both port and domestic flows. This mixture causes problems with matching directional imbalances but also raises complications with different wagon and container types, as discussed in the next section. Generally, port flows are nonfood lines such as clothes or electronics from the Far East moving through UK deepsea ports such 
as Felixstowe and Southampton. Tesco is the largest retailer and imports roughly 20,000 containers per year from the Far East through these two ports. This translates to about 400 loads per week.

Not all retailers have the resources or the desire to manage primary distribution, as there are pros and cons to managing it in-house, sub-contracting to one or more firms or leaving it to suppliers. For example, Sainsbury manages about $90 \%$ of their inbound fresh produce, $60 \%$ of chilled and $10 \%$ of ambient/grocery, whereas Tesco has a larger focus on primary distribution, with $60 \%$ of ambient/grocery and $70 \%$ of fresh produce moving through their primary network. Tesco's high level of control of primary ambient flows enables them to put this supplier traffic on rail, providing backhaul flows south to the Midlands to balance the northbound secondary movements.

These decisions are different for different companies, thus a wholesaler like Costco has a simpler model. They only have about 3,200 stock-keeping units (SKUs), so this is very different to a supermarket retailer, as it allows Costco to maintain a far simpler operation. All primary flows are delivered as full container loads (FCL) and managed by the suppliers; moreover, all value-added work is pushed upstream as supply chain management is not the core competency of Costco.

The role of shipping lines should also be considered. The UK is unusual in Europe in having a high proportion of carrier haulage (about 70\%), which means that the shipping lines control distribution from the port to the inland destination. When this is done by rail, it is usually with Freightliner on their ex port services, although DB Schenker has been competing successfully in this market. As carrier haulage gives less control to the retailers, this is one area in which a large company like Tesco, with growing experience at managing their primary network, can negotiate port-only prices and manage the inland leg themselves. The flows that they currently manage in this way are going by road, but their next step is to shift some of these flows (mostly Felixstowe/Southampton to Daventry) to rail.

\subsection{Secondary distribution}

Movements from DCs to stores are more likely to be managed in-house by the retailer or subcontracted on a closer relationship. Tesco, Sainsbury and the Co-operative all run their own trucks for secondary distribution but will sub-contract occasionally where required, as well as some of the retail lorry fleet being operated by third parties on an open-book basis (see Table 5). A large supermarket would have on average about 5-6 trucks delivering per day (obviously this depends on a number of factors such as use of double-deck lorries). 
Table 5. Distribution structure of each company

\begin{tabular}{|c|c|c|c|c|}
\hline Company & Sector & $\begin{array}{c}\text { Manage primary } \\
\text { distribution }\end{array}$ & Manage secondary distribution & DCs \\
\hline Tesco & Retailer & Partial - high & Yes & 24 \\
\hline Sainsbury & Retailer & Partial - med & $\begin{array}{c}\text { Yes, but about 50\% on third } \\
\text { party open-book basis }\end{array}$ & 22 \\
\hline The Cooperative & Retailer & No & Yes & 16 \\
\hline Costco & Wholesaler & No & Yes & 1 \\
\hline
\end{tabular}

Whether secondary flows are suitable for rail will depend to a large degree on the distribution strategy of the retailer, for example which product lines are stored at the regional distribution centre (RDC) and which require trunking from the national distribution centre (NDC). For example, when Tesco moves containers by rail from Daventry to Livingston, each container is designated for a specific store, with the relevant cages from Daventry inside. At Livingston they add additional cages to the container, then send it by truck to the store. This is done in the trunking station which is all cross-docked. The Stobart Tesco train to Inverness also takes boxes for specific stores, but rather than being a DC to DC move, these boxes are trucked direct from the terminal to stores by JG Russell.

Opened in 2007, Tesco's large 1 million square foot DC at Livingston is the only Tesco DC that has fresh, grocery, frozen, trunking and recycling all within the same facility. It sends around 4.5 million cases weekly to about 250 stores across Scotland, north England and Northern Ireland. There are 7,500 SKUs in the grocery part of Livingston DC alone. Tesco monitors which lines should be picked at Daventry and trunked to Livingston and which should be stored there. It changes as different lines rise and fall in sales, however, all fresh food in Scotland moves through Livingston. On an average day the Livingston DC has around 900 trucks coming in and out, but this is an unusually large site.

Lead time is crucially important for all movements between DCs and stores. According to interviewees, an ideal scenario would involve overnight picking and morning departure from the DC to reach the store by mid-afternoon, but this cannot always be done because of passenger trains on the line during the day. Unless this can be resolved, intermodal growth will be constrained by operating mostly at night, which requires stores to order from DCs in the morning so that the load can be picked in the afternoon, loaded at the DC at say 1600 to catch a 2000 departure on the train, which will then arrive at its destination in the early morning (say 0400-0500) for trucking to the store. 


\subsection{Centralisation and other models}

The geographical coverage of distribution facilities is being rationalised by the leading retailers to improve the efficiency of their supply chains; however, legacy issues determine to a large extent where the DCs are located, meaning that they do not begin today with a blank map. Most retailers prefer a centralised model but other models have some potential, such as port-centric logistics and continental hubs.

Both Asda and Tesco have recently opened distribution centres to deal with imports at the port of Teesport in the northeast of the UK. Interviews revealed that Tesco does not currently ship anything through this port, instead bringing containers from the ports of Felixstowe and Southampton, which indicates that even with port-centric strategies, centralisation tendencies are very hard to overcome. This could be because Tesco has fewer stores in the northeast than Asda so the port-centric strategy was not suitable to their store coverage.

Interviewees questioned the operational aspects of port-centric logistics, and it was suggested that backhaul and container type issues may be difficult to overcome. If the DC is in the port then imports arrive in maritime containers, are emptied in the DC then the empty goes back to the shipping line. The goods are then distributed from the DC to the stores in $45 \mathrm{ft}$ lorries, but the only lorries coming to the port will be bringing maritime containers, so it can be difficult to match these flows. The result could be empty lorries coming to the DC. Another downside is that the company is anchored at that port with little option if a shipping line raises its prices or moves to another port.

Another option is to make use of a continental hub to consolidate flows then bring them to the UK by rail or ferry. Tesco/Stobarts work with $2 \mathrm{XL}$ in Zeebrugge to consolidate loads there (Red Bull for example). Similarly, French wine used to come in full loads but now Tesco de-stuffs them at Zeebrugge and consolidates many different loads into one container which can then go direct to the store in the UK. This means they also reduce their inventory from six weeks down to one week. There are difficulties in this model, however. The Channel Tunnel rates are considered by some interviewees to be high, part-load patterns are complex, and the ferry also has constraints such as time, frequency and imbalance of flows.

\section{Strategies of integration influencing the use of rail transport}

\subsection{Vertical}

Both vertical and horizontal integration can be observed in the industry, however it is the former that is having the greatest impact. Most noticeable is the relationship between retailer Tesco, logistics provider Stobart and rail operator DRS. Working closely together has allowed all parties to develop knowledge of requirements and adjust operations to suit as they plan new services and solve operational issues as they arise. 
Vertical integration between all levels of rail operations (from terminal operation, traction provision, train management and road haulage) presents an interesting dynamic. Terminals can be run by rail operators (e.g. Freightliner or DB Schenker), 3PLs (e.g. WH Malcolm) or other companies (e.g. ABP at Hams Hall), or even be private sidings for which the operation is subcontracted (e.g. Stobart operating the Tesco siding at DIRFT). Likewise, the customer side of trains is normally managed by a 3PL rather than the rail operator (e.g. JG Russell, WH Malcolm and Stobart operating trains with traction provided by DRS or DB Schenker), but for other trains the management is also done by the rail operator (e.g. Freightliner or DB Schenker). Therefore various levels of vertical integration exist depending on the particular service.

Considering international collaboration, Stobart Rail runs a weekly train during the winter carrying fruit from Valencia in Spain in thirty 45ft refrigerated containers through France and the Channel Tunnel into the JG Russell terminal at Barking. The goal is to grow to 2-3 services per week, which would ensure better asset utilisation, making the service more economic. That is the basis on which they applied for Marco Polo funding because to get that funding the service needs to be feasible within 3 years. However operational issues on the journey through France (this leg operated by $\mathrm{SNCF}$ ) has resulted in late arrivals, threatening the viability of the service.

\subsection{Horizontal}

Retailers do not currently share space within containers, but their containers travel together on multi-user 3PL trains as noted earlier. 3PLs also share space on their services, usually on an ad hoc basis, but as ex-port services are mostly run by Freightliner who specialises in these flows, 3PLs will buy space on those trains (e.g. Stobart bringing boxes from Tilbury to their hub at Widnes). 3PLs can collaborate in other ways, for example, Stobart runs the Tesco train from Mossend to Inverness, where it terminates at the JG Russell terminal, from which point JG Russell distributes the containers to stores by road. However, while 3PLs will share spare on each other's services when needed, they do not actually run any regular services together.

At the present time, Tesco is the only retailer large enough to fill a complete train. However, the decision is whether to operate a dedicated service, in which case the retailer pays for the whole train and therefore must take responsibility for filling any empty wagons or suffer a financial penalty. Scheduled services may be used by any shippers, but having a dedicated train grants more control over the timings and operation of the service. Establishing a dedicated Tesco train rather than just buying space on a third-party service gives them more control and enables them to plan the primary and secondary distribution as part of a unified system.

The retail interviews revealed that in an ideal scenario they would all prefer to have their own rail-connected sheds rather than using a shared terminal to load a multi-user train. This practice 
would require a full trainload per user, reducing opportunities for collaboration. The new DIRFT 3 appears to be planned around this model of more rail-connected sheds. Similarly, the new DC being built by $M \& S$ at Castle Donington is rail-connected, but without the retailer being able to provide enough volume for regular services, this development will make asset utilisation more difficult for rail operators. It can only work if an operator (or someone else) can provide more rail flows to this terminal to get better utilisation of the rolling stock.

\section{Applying the conceptual framework}

Following Miles \& Huberman (1994), Table 6 uses a meta-matrix to analyse the key factors from the conceptual framework. The table summarises the expectations from the literature review (drawing on Table 1) and compares them with the findings from the UK case, highlighting where expectations have been confirmed and where new findings have been established. 
Table 6. Meta-matrix applying the conceptual framework to the data

\begin{tabular}{|c|c|c|c|}
\hline Factor & Sub-factor & Literature & Findings \\
\hline \multirow{5}{*}{$\begin{array}{l}\text { Operational } \\
\text { rail issues }\end{array}$} & Infrastructure & $\begin{array}{l}\text { Capacity and high-cube } \\
\text { clearance issues are } \\
\text { known. }\end{array}$ & $\begin{array}{l}\text { This was confirmed. Government investment is ongoing } \\
\text { but daytime capacity issues will not be resolved. }\end{array}$ \\
\hline & Equipment & $\begin{array}{l}\text { Wagon and container } \\
\text { imbalances are known. }\end{array}$ & $\begin{array}{l}\text { This was confirmed, although greater detail was } \\
\text { established regarding the relations of Scottish exports } \\
\text { ( } 20 / 40 \mathrm{ft}) \text {, northbound retail flows ( } 45 \mathrm{ft} \text { pallet-wide) and } \\
\text { intra-European containers ( } 45 \mathrm{ft} \text { pallet-wide), as well as } \\
\text { wagon configurations }(60 \mathrm{ft} / 54 \mathrm{ft} / 45 \mathrm{ft}) \text {. Another particular } \\
\text { issue for retailers is the use of cages which suits double- } \\
\text { deck lorries. }\end{array}$ \\
\hline & Operations & $\begin{array}{l}\text { Known issues with lead } \\
\text { time, backhauls, service } \\
\text { development and } \\
\text { general operational } \\
\text { complexities compared } \\
\text { to road transport. } \\
\text { The literature assumes a } \\
\text { competitive } \\
\text { environment for } \\
\text { domestic rail. } \\
\text { Little discussion of port } \\
\text { vs inland flows. }\end{array}$ & $\begin{array}{l}\text { Generally confirmed, but, contrary to the common } \\
\text { approach in the literature, the importance of asset } \\
\text { utilisation rather than simple breakeven distance was } \\
\text { raised in the interviews. } \\
\text { A new finding was that the image of rail amongst users } \\
\text { has improved and all shippers in this research said they } \\
\text { were happy with the reliability of rail. } \\
\text { All but one service on the Anglo-Scottish route used by } \\
\text { retailers is provided by one rail operator (although other } \\
\text { intermodal services exist), so less "on-rail" competition } \\
\text { than was thought. A separation between port and } \\
\text { domestic flows (also linked to equipment issues) was } \\
\text { found, which constrains the wider economic feasibility of } \\
\text { rail. }\end{array}$ \\
\hline & Price & $\begin{array}{l}\text { Lack of transparent } \\
\text { pricing system. }\end{array}$ & $\begin{array}{l}\text { This was confirmed, with more detail on the issue. Some } \\
\text { shippers say that they would like greater visibility of the } \\
\text { cost to the provider of the entire rail service, including } \\
\text { the trunk haul, so that they know what the prices are } \\
\text { based on. }\end{array}$ \\
\hline & $\begin{array}{l}\text { Role of } \\
\text { government in } \\
\text { intermodal } \\
\text { transport }\end{array}$ & $\begin{array}{l}\text { Government promotes } \\
\text { intermodal transport } \\
\text { through policy. } \\
\text { Literature suggests that } \\
\text { government funding for } \\
\text { intermodal transport has } \\
\text { been successful. }\end{array}$ & $\begin{array}{l}\text { The role of government was considered more in terms of } \\
\text { infrastructure upgrades than direct intervention in } \\
\text { operations. } \\
\text { Planning consent for more single-user sites could split } \\
\text { scale economies, but shippers prefer their own } \\
\text { connections rather than sharing either trains or terminals. } \\
\text { Confirmed that government grants have been } \\
\text { instrumental in supporting the shift from road to rail, } \\
\text { although some concerns that the FFG system could have } \\
\text { been used more strategically. }\end{array}$ \\
\hline
\end{tabular}




\begin{tabular}{|c|c|c|c|}
\hline \multirow{5}{*}{$\begin{array}{l}\text { Retail } \\
\text { distribution }\end{array}$} & $\begin{array}{l}\text { Primary } \\
\text { distribution }\end{array}$ & $\begin{array}{l}\text { Generally managed by } \\
\text { suppliers but increasing } \\
\text { control by retailers. }\end{array}$ & $\begin{array}{l}\text { This was confirmed. Only one retailer (Tesco) is engaged } \\
\text { in FGP. }\end{array}$ \\
\hline & $\begin{array}{l}\text { Secondary } \\
\text { distribution }\end{array}$ & $\begin{array}{l}\text { Generally managed by } \\
\text { retailers now. }\end{array}$ & This was confirmed. \\
\hline & $\begin{array}{l}\text { Distribution } \\
\text { centres }\end{array}$ & $\begin{array}{l}\text { Rationalisation and } \\
\text { centralisation of DCs, } \\
\text { larger purpose-built } \\
\text { composites. }\end{array}$ & $\begin{array}{l}\text { This was confirmed. Additional point of relevance is that } \\
\text { very few have rail connections. } \\
\text { Some uses of port-centric logistics and continental hubs } \\
\text { were revealed, but the latter is mostly for some niche } \\
\text { products like wine, whereas the former has operational } \\
\text { limitations. }\end{array}$ \\
\hline & Consolidation & $\begin{array}{l}\text { Use of PCCs by } \\
\text { suppliers. }\end{array}$ & $\begin{array}{l}\text { This was confirmed, but the new finding was the lack of } \\
\text { appetite for third-party consolidation in secondary } \\
\text { distribution, which relates to the lack of horizontal } \\
\text { integration observed. 3PLs seem more focused on } \\
\text { solving operational issues while retailers are more } \\
\text { concerned with managing their own business rather than } \\
\text { altering it to suit larger collaborative interests such as } \\
\text { intermodal transport requires. }\end{array}$ \\
\hline & $\begin{array}{l}\text { Product \& } \\
\text { route } \\
\text { characteristics }\end{array}$ & $\begin{array}{l}\text { Primarily } \\
\text { ambient/grocery } \\
\text { products in retail cages } \\
\text { moving in containers on } \\
\text { the Anglo-Scottish } \\
\text { route, back hauled by } \\
\text { suppliers. Long distance } \\
\text { route between load } \\
\text { centres located in the } \\
\text { Midlands and central } \\
\text { Scotland. }\end{array}$ & $\begin{array}{l}\text { This was confirmed, but the role of port flows was noted. } \\
\text { Palletised (and sometimes break bulk) general } \\
\text { merchandise in 20/40ft deepsea containers vs domestic } \\
\text { ambient in } 45 \mathrm{ft} \text { pallet-wide containers. } \\
\text { Different product characteristics (e.g. grocery focus on } \\
\text { domestic links vs general merchandise on port links) } \\
\text { affect the ability to manage intermodal transport } \\
\text { efficiently. } \\
\text { Logistics decisions take precedence over transport. Even } \\
\text { Tesco, the leader in intermodal use, built their Scottish } \\
\text { DC at Livingston right next to a rail line but did not build } \\
\text { a rail connection. }\end{array}$ \\
\hline \multirow[b]{2}{*}{ Integration } & Horizontal & $\begin{array}{l}\text { Uncommon among } \\
\text { retailers but some } \\
\text { evidence that 3PLs are } \\
\text { increasingly doing so. }\end{array}$ & $\begin{array}{l}\text { This was confirmed. This could be a significant barrier to } \\
\text { greater use of intermodal transport. }\end{array}$ \\
\hline & Vertical & $\begin{array}{l}\text { Increasingly integrated } \\
\text { supply chains but little } \\
\text { in the literature } \\
\text { regarding its role in } \\
\text { intermodal transport. }\end{array}$ & $\begin{array}{l}\text { Vertical integration is more common than horizontal, as } \\
\text { it is necessary in the modern complicated logistics and } \\
\text { transport environment. Thus it is Tesco/Stobart/DRS } \\
\text { collaborating the most because they are the main } \\
\text { intermodal configuration. 3PLs are becoming } \\
\text { increasingly important to intermodal transport. }\end{array}$ \\
\hline
\end{tabular}




\section{Discussion}

Many of the findings from the British case corroborate the previous research discussed in the literature review. However, the case has added new knowledge which is relevant not only to the UK retail sector but also to comparable market sectors within the UK as well as other regions with similar market and geographical characteristics, such as continental Europe.

The examination of the rail industry revealed that the intermodal market is growing, but while healthy competition is observed between three 3PLs, traction for all but one of the services is provided by one operator, confirming suggestions in the literature that it is not an easy market to enter. There is only one retailer (Tesco) with significant volume, although Asda is making efforts with both rail services and their port-centric import centre, due partly to their greater concentration of stores in the northeast.

The key flow is ambient grocery on the Anglo-Scottish route though non-food port flows are relevant, for example Tesco seeking to replace carrier haulage with their own primary network. Intermodal terminals for these flows in England and Scotland were identified along with current service provision. It was found that government funding has been essential in upgrading freight handling facilities at many UK intermodal terminals, and that annual operational subsidies of $£ 2.8 \mathrm{~m}$ underpin the services discussed in this paper.

From an operational perspective, it was found that asset utilisation is key for rail operators as expensive assets are forced to remain idle while daytime paths are used by passenger trains. This also relates to the lack of horizontal cooperation between retailers in terms of providing enough flows for each train. Other known operational issues such as wagon and container management play crucial roles; it was seen in this case how the container imbalance on the Anglo-Scottish corridor increases the difficulty of sourcing backhauls which are essential to the economic viability of these services. This imbalance in both flows and equipment is exacerbated by the lack of coordination between domestic and port movements. While these flows may be managed by different parts of the retail organisation (e.g. grocery focus on domestic flows and general merchandise for port flows), intermodal transport efficiency requires that they be considered together.

Analysis of the spatial development of the retail sector confirmed the centralisation of DCs identified in the literature. There are some potential drivers for decentralisation, such as port-centric logistics and continental hubs, but the analysis in this paper has suggested that they have only limited potential. Centralisation has facilitated trunk hauls between NDCs and DCs, thus being a key reason behind the success of retail intermodal logistics, however different practices have been observed in the present research. For example, sending a full container from Midlands NDC to Scottish rail terminal and direct to store (e.g. the Cooperative) is different to sending a partially-full 
container from the NDC to the Scottish DC where further cages are added in the trunking station, and thence to the store (e.g. Tesco).

The literature suggested increasing integration between actors but was unclear on the extent and the process by which it is done. Horizontal integration is important to achieve full trains, and while the results showed that this is happening now between 3PLs, it is not happening with retailers. Findings from this case raise the issue of retailers preferring private sidings rather than shared-user terminals, which splits economies of scale and can be a barrier to greater use of intermodal transport. Public planners might consider whether multi-user platforms should be preferred in the planning system rather than more rail-connected sheds. Vertical integration is more common than horizontal, as was to be expected, as actors see that this is an important element in making intermodal transport work.

By studying the role of 3PLs as well as retailers, this paper has demonstrated the value of taking a broader approach to the support of intermodal service development. For example, 3PLs raised the importance of consolidation centres for converting LCL into FCL which can feed intermodal services if they are located at intermodal hubs, in particular southbound flows on the Anglo-Scottish route to provide backhauls for northbound retail flows. They can also be used for retailers destuffing containers and consolidating loads for regional stores. This could also be considered by public planners.

In the interviews, 3PLs seemed confident that intermodal use will increase, but while retailers are positive about intermodal, actions show that it remains a minority interest. Indeed, it was unclear to what degree a company's interest in using rail is due to a shift in the sector or a purposeful management policy or whether it is just down to an individual in a company. Therefore it is difficult to drive this through policy when it often comes down to individuals, meetings and discussions between 3PL or rail personnel and the potential client, built on individual relationships. The role of the individual decision maker within an organisation could be a subject for future research.

Future drivers of rail growth include fuel price rises, carbon targets and increasing road congestion, particularly in areas where the road is poor. Fuel price is certainly an issue, as some operators update their costs on their contract weekly due to changing fuel costs. Congestion is less of an issue at the moment but will not go away, and corporate social responsibility has grown in importance, according at least to company reports and promotional literature (Jones et al., 2005). While the green agenda may have fallen slightly in prominence due to the recession, it remains a key driver, according to interviewees. 


\section{Conclusion}

While the relationship between distribution geography and rail operations discussed in this paper was based on retailers, many of these features are observed in other industry sectors, so these findings can be applied in other market contexts. Many of these operational issues, observed in both the literature and the present research, have no sign of a solution, such as short distances, fragmented flows, backhaul sourcing, reluctance to share trains, container imbalances and lack of day time paths limiting lead times and asset utilisation. Ongoing public subsidy is still provided, which could be removed at any point. Thus even the most successful users of intermodal transport have made only small advances towards solving the perennial problems identified in the literature.

A key outcome of this paper that can be applied in other contexts arises from the conceptual framework used in this research, which included retailers, 3PLs and rail operators as they all combine to produce successful retail intermodal logistics. Rail operation in the UK is competitive but as one provider has become more experienced and built better relationships with retailers and 3PLs, this one provider now dominates and entering this market will be difficult for others. From a retailer perspective, only one large retailer is directly involved in intermodal logistics, while the others only participate through the use of 3PLs. Thus the 3PL is the main player in retail intermodal logistics in the UK, with high competition between three providers, all of which have been successful in attracting and aggregating small flows. The potential role of the 3PL in supporting intermodal transport is a finding that can be explored in other contexts, and is of particular relevance to transport planners.

While government funding in the past has supported both single-user and multi-user intermodal terminals, new developments include private sidings to support retailer preference; this approach may have limited success because it does not sufficiently incorporate the role of the 3PLs. The operational constraints discussed above require the 3PL to provide a necessary bridge between the retailer and the rail operator. 3PLs require the prioritisation of consolidation centres and multi-user terminals, supporting the aggregation that underpins the financial viability of rail transport. This limitation in the current system can be addressed in future research, as well as being translated to other market and geographical contexts and informing government approaches to the support of intermodal transport.

\section{Acknowledgements}

The author would like to thank all interviewees who shared their time and knowledge, as well as acknowledge the contribution of Gavin Roser from Pantrak Transportation Ltd who assisted in arranging many of the interviews. Research for this paper was supported by the Interreg IVB programme Dryport and Foodport projects, funded by the European Commission. 


\section{References}

Aastrup, J. and Halldórsson. A., 2008. Epistemological role of case studies in logistics; a critical realist perspective. International Journal of Physical Distribution and Logistics Management, 38 (10), 746-763.

Abrahamsson, M. and Brege, S., 1997. Structural changes in the supply chain. International Journal of Logistics Management, 8 (1), 35-44.

Arnold, P., Peeters, D. and Thomas, I., 2004. Modelling a rail/road intermodal transportation system. Transportation Research Part E, 40 (3), 255-270.

Bärthel, F. and Woxenius, J., 2004. Developing intermodal transport for small flows over short distances. Transportation Planning and Technology, 27 (5). 403-424.

Burt, S. L. and Sparks, L., 2003. Power and competition in the UK retail grocery market. British Journal of Management, 14 (3), 237-254.

Caris, A, Macharis, C. and Janssens, G. K., 2008. Planning problems in intermodal freight transport: accomplishments and prospects. Transportation Planning \& Technology, 31 (3), 277-302.

da Mota Pedrosa, A., Näslund, D. and Jasmand, C., 2012. Logistics case study based research: towards higher quality. International Journal of Physical Distribution \& Logistics Management, 42 (3), 275-295.

DETR, 1998. A New Deal for Transport: Better for Everyone, Department of the Environment, Transport and the Regions, London.

Department for Transport, 2011. DfT Port Statistics. DfT, London.

Eng-Larsson, F. and Kohn, C., 2012. Modal shift for greener logistics - the shipper's perspective. International Journal of Physical Distribution and Logistics Management, 42 (1), 36-59.

European Commission. 2001. European Transport Policy for 2010: Time to Decide, European Commission, Luxembourg.

Fernie, J. and McKinnon, A., 1991. The impact of changes in retail distribution on a peripheral region: the case of Scotland. International Journal of Retail \& Distribution Management, 19 (7), 25-32.

Fernie, J. and McKinnon, A.C., 2003. The Grocery Supply Chain in the UK: Improving Efficiency in the Logistics Network. International Review of Retail, Distribution and Consumer Research, $13(2), 161-74$.

Fernie, J., Pfab, F. and Merchant, C., 2000. Retail grocery logistics in the UK. International Journal of Logistics Management, 11 (2), 83-90. 
Fernie, J., Sparks, L. and McKinnon, A. C., 2010. Retail logistics in the UK: past, present and future. International Journal of Retail and Distribution Management, 38 (11/12), 894-914.

Flyvbjerg, B., 2006. Five misunderstandings about case-study research. Qualitative Inquiry, 12 (2), 219-245.

Forum for the Future, 2007. Retail futures; scenarios for the future of UK retail and sustainable development. Forum for the Future, London.

FTA, 2012. On track: Retailers using rail freight to make cost and carbon savings. FTA, London.

Hingley, M, Lindgreen, A., Grant, D. B. and Kane, C., 2011. Using fourth-party logistics management to improve horizontal collaboration among grocery retailers. Supply Chain Management: An International Journal. 16 (5), 316-327.

IGD, 2009. UK Food \& Grocery Retail Logistics Overview. available at http://www.igd.com/index.asp?id=1\&fid=1\&sid=3\&tid=42\&cid=223 (accessed 24 September 2012).

IGD, 2012. Over 200 million food miles removed from UK roads. available at http://www.igd.com/print.asp?pid=1\&pflid=6\&plid=5\&pcid=2303 (accessed 11 April 2012).

Janic, M., 2007. Modelling the full costs of an intermodal and road freight transport network. Transportation Research Part D: Transport and Environment, 12 (1), 33-44.

Jones, P., Comfort, D. and Hillier, D., 2005. Corporate social responsibility and the UK's top ten retailers. International Journal of Retail and Distribution Management, 33 (12), 882-892.

Jones, P., Comfort, D. and Hillier, D., 2008. UK retailing through the looking glass. International Journal of Retail and Distribution Management, 36 (7), 564-570.

Kreutzberger. E. D. 2008. Distance and time in intermodal goods transport networks in Europe: a generic approach. Transportation Research Part A: Policy \& Practice, 42 (7), 973-993.

Kumar, S., 2008. A study of the supermarket industry and its growing logistics capabilities. Internatoinal Journal of Retail and Distribution Management, 36 (3), 192-211.

Lemoine, O. W. and Skjoett-Larsen, T., 2004. Reconfigurations of supply chains and implications for transport; a Danish study. International Journal of Physical Distribution and Logistics Management, 34 (10), 793-810.

Lloyd's List, 2011. CMA CGM signs two-year rail deal with DB Schenker at Southampton. available at http://www.lloydslist.com/ll/sector/ports-and-logistics/article368643.ece (accessed $16^{\text {th }}$ March 2012).

Mangan, J., Lalwani, C. and Fynes, B., 2008. Port-centric logistics. The International Journal of Logistics Management, 19 (1), 29-41. 
Mason, R., Lalwani, C. and Boughton, R., 2007. Combining vertical and horizontal collaboration for transport optimisation. Supply Chain Management: An International Journal, 12 (3), 187199.

McKinnon, A. C., 1994. Channel Tunnel freight services between Scotland and continental Europe: an examination of the opportunities and constraints. Applied Geography, 14 (1), 68-86.

McKinnon, A., 2009. The present and future land requirements of logistical activities. Land Use Policy, 26S, S293-S301.

McKinnon, A., 2010. Britain without double-deck lorries, Heriot-Watt University, Edinburgh.

MDS Transmodal Ltd., 2002. Opportunities for developing sustainable freight facilities in Scotland. report prepared for the Scottish Executive, Edinburgh.

Miles, M. B. and Huberman, A. M., 1994. Qualitative Data Analysis, Sage, Thousand Oaks, CA.

Monios, J. and Wilmsmeier, G., 2012. Port-centric logistics, dry ports and offshore logistics hubs: strategies to overcome double peripherality? Maritime Policy and Management, 39 (2), 207226.

Monios, J. and Wilmsmeier, G., 2014. The impact of container type diversification on regional British port development strategies. Transport Reviews, 34 (5), 583-606.

Näslund, D., 2002. Logistics needs qualitative research - especially action research. International Journal of Physical Distribution and Logistics Management, 32 (5), 321-338.

Network Rail, 2007. Freight Route Utilisation Strategy, Network Rail, London.

O’Laughlin, K. A., Cooper, J C. and Cabocal, E., 1993. Reconfiguring European Logistics Systems, CLM, Oak Brook.

Pettit, S. J., Beresford and A. K. C., 2009. Port development: from gateways to logistics hubs. Maritime Policy \& Management, 36 (3), 253-267.

Potter, A., Mason, R. and Lalwani, C., 2007. Analysis of factory gate pricing in the UK grocery supply chain. International Journal of Retail and Distribution Management, 35 (10), 821-834.

RHA, 2007. Inhibitors to the Growth of Rail Freight. Scottish Executive, Edinburgh.

Runhaar, H. and van der Heijden, R., 2005. Public policy intervention in freight transport costs: effects on printed media logistics in the Netherlands. Transport Policy, 12 (1), 35-46.

Schmoltzi, C. and Wallenburg, C. M., 2011. Horizontal cooperations between logistics service providers: motives, structure, performance. International Journal of Physical Distribution and Logistics Management, 41 (6), 552-576.

Scottish Government, 2010. Food and Drink in Scotland: Key Facts 2010, Scottish Government, Edinburgh.

Seuring, S. A., 2008. Assessing the rigor of case study research in supply chain management. Supply Chain Management: An International Journal, 13 (2), 128-137. 
Slack, B. and Vogt, A., 2007. Challenges confronting new traction providers of rail freight in Germany. Transport Policy, 14 (5), 399-409.

Smith, D. L. G. and Sparks, L., 2009. Tesco's supply chain management. In: Fernie, J. and Sparks, L. (Eds.), Logistics and Retail Management, 3rd ed., Kogan Page, London, pp. 143-71.

Spens, K. M. and Kovács, G., 2006. A content analysis of research approaches in logistics research. International Journal of Physical Distribution and Logistics Management, 36 (5), 374-390.

Towill, D. R., 2005. A perspective on UK supermarket pressures on the supply chain. European Management Journal, 23 (4), 426-438.

Van der Horst, M. R. and De Langen, P. W., 2008. Coordination in hinterland transport-chains: a major challenge for the seaport community. Maritime Economics \& Logistics, 10 (1-2), 108129.

Van Schijndel, W. J. and Dinwoodie, J., 2000. Congestion and multimodal transport: a survey of cargo transport operators in the Netherlands. Transport Policy, 7 (4), 231-241.

Wilmsmeier, G. and Monios, J., 2013. Counterbalancing peripherality and concentration: an analysis of the UK container port system. Maritime Policy \& Management, 40 (2), 116-132.

Woodburn, A., 2003. A logistical perspective on the potential for modal shift of freight from road to rail in Great Britain. International Journal of Transport Management, 1 (4), 237-245.

Woodburn, A., 2007. Evaluation of rail freight facilities grants funding in Britain. Transport Reviews, 27 (3), 311-326.

Woodburn, A., 2011. An investigation of container train service provision and load factors in Great Britain. European Journal of Transport and Infrastructure Research, 11 (2), 147-165.

Woodburn, A., 2012. Intermodal rail freight activity in Britain: where has the growth come from? Research in Transportation Business \& Management. 5 (1), 16-26. 